\title{
Curcumin Attenuates Lipopolysaccharide-Induced Renal Inflammation
}

\author{
Fang Zhong, Hui Chen, Lin Han, Yuanmeng Jin, and Weiming WANG* \\ Department of Nephrology, Ruijin Hospital, Shanghai Jiao Tong University, School of Medicine; Shanghai 200025, P. R. \\ China. Received June 14, 2010; accepted October 15, 2010; published online November 24, 2010
}

\begin{abstract}
Renal inflammation is the main pathological change in many acute and chronic kidney diseases. Curcumin, a yellow pigment present in the rhizome of turmeric (Curcuma longa $\mathrm{L}$. Zingiberaceae), was found to be a potential anti-inflammatory agent. The present study aimed to investigate the effects of curcumin on the inflammation of mice kidney and cultured renal tubular epithelial cells (HK-2 cells) induced by lipopolysaccharide (LPS) and to explore the mechanism. Curcumin was injected intraperitoneally before LPS administration. Renal inflammation was assessed by evaluating monocyte chemoattractant protein-1 (MCP-1) expression and macrophage infiltration in renal tissue using immunohistochemical methods, and also by measuring renal MCP-1 mRNA level using Real-Time polymerase chain reaction (PCR). HK-2 cells were cultured to investigate the in vitro effect of curcumin against LPS-induced renal inflammation. The expression of MCP-1 and interleukin-8 (IL-8) mRNA was measured by Real-Time PCR. The expression of MCP-1 and IL-8 protein in supernatant was detected by enzyme-linked immunosorbent assay (ELISA). The activity of nuclear factor (NF)- $\kappa B$ was detected by electrophoretic mobility shift assay (EMSA). The results demonstrated that curcumin could inhibit LPS-induced renal MCP-1 mRNA expression. Curcumin also significantly inhibited the expression of MCP-1 and IL-2 mRNA in HK-2 cells, and partially inhibited the secretion of MCP-1 and IL-8. Furthermore, curcumin was found to inhibit the DNA-binding activity of NF- $\kappa B$. The present study demonstrated that curcumin has a protective effect on LPS-induced experimental renal inflammation, and this effect might be attributed to its inhibitory effects on MCP-1 mRNA expression and DNA-binding activity of NF- $K B$. Hence, curcumin might be potentially useful in some kidney diseases by preventing renal inflammation.
\end{abstract}

Key words cucurmin; renal tubular epithelial cell; lipopolysaccharide; monocyte chemoattractant protein-1; interleukin 8

Curcumin is a bright yellow compound found in turmeric, which is derived from the rhizomes of the plant Curcuma longa LinN, a perennial herb of the Zingerberaceae family.1) It has been used for millennia as a wound-healing agent and for treating a large number of diseases in traditional Chinese and Indian medicine. ${ }^{2)}$ A wide variety of cellular properties of curcumin have been demonstrated, including anti-inflammatory, antioxidant, antiproliferative, pro-apoptotic, anti-bacterial and anti-cancer activities. ${ }^{3)}$ Among all these biological activities, the anti-inflammatory effects of curcumin have been assessed in various in vitro systems and in experimental animal systems. ${ }^{4,5)}$ Renal inflammation is the main pathological change in many acute and chronic kidney diseases. Several studies have demonstrated that curcumin played a positive role in inflammation-related renal injury using various animal models, ${ }^{6-10)}$ of which only one study used cultured cell lines as the in vitro model. ${ }^{10)}$ Lipopolysaccharide (LPS), the product of Gram-negative bacteria, is an important inflammatory factor and has been widely used to induce renal inflammation models when studying inflammation-related renal diseases. ${ }^{11-13)}$ This model was also employed in the present study to investigate the effect of curcumin on renal inflammation. In a variety of acute and chronic renal inflammation, renal tubular epithelial cells were not only the victims, but also actively participate in the process of glomerular sclerosis and renal fibrosis by secreting a variety of inflammatory chemokines and extracellular matrix. Considering the important role renal tubular epithelial cells played in renal inflammation, a human proximal tubule cell line (HK-2 cells) was selected as the in vitro model. By using both in vitro and in vivo models, we attempted to obtain an allaround evaluation of curcumin on renal inflammation, and also gain a preliminary view of the underlying mechanism.

\section{MATERIALS AND METHODS}

Chemicals Keratinocyte-serum-free medium (SFM) cell culture medium, fetal bovine serum, trypsin, and Trizol RNA extraction reagent were purchased from Gibco Life Technologies, Inc. (Grand Island, NY, U.S.A.). Reverse transcription-polymerase chain reaction (RT-PCR) related reagents such as moloney murine leukemia virus (M-MLV) reverse transcriptase, deoxyribonucleotide triphosphate (dNTP), random primers and RNase inhibitor were obtained from Promega Corp. (Madison, Wisconsin, U.S.A.). Curcumin and lipopolysaccharide (LPS, Escherichia coli 0111: B4) were products of Sigma-Aldrich Chemical Co. (St. Louis, MO, U.S.A.). SYBR GREEN Mix Kit was from TOKOBO (Osaka, Japan). PCR primers of glyceraldehyde-3-phosphate dehydrogenase (GAPDH), Interleukin-8 (IL-8) and monocyte chemotactic protein 1 (MCP-1) were synthesized by Sangon Biotech Co., Ltd. (Shanghai, China). MCP-1 and IL-8 enzyme-linked immunosorbent assay (ELISA) kits were purchased from Biosource International, Inc. (Camarillo, CA, U.S.A.).

Cell Culture HK-2 cells, an immortalized proximal tubular epithelial cell (PTEC) line from normal adult human kidney, were obtained from the American Type Culture Collection (Manassas, VA, U.S.A.). HK-2 cells were cultured in Keratinocyte-SFM cell culture medium containing $2 \%$ fetal calf serum at $37^{\circ} \mathrm{C}$ and $5 \% \mathrm{CO}_{2}$.

Animals Kunming mice of specific pathogen free (SPF) level (6-8 weeks old), ranging from 18 to $22 \mathrm{~g}$, were purchased from the Laboratory Animal Center of Shanghai Jiao Tong University (Shanghai, China). The animals were maintained under climate-controlled conditions with a 12-h light/dark cycle, and were fed standard rodent chow and water. The guidelines for the care of the animals were strictly 
followed throughout the study.

Animal Experiments Kunming mice were divided into three groups. Group I comprised control animals that received an intraperitoneal injection of saline. Group II (LPS group) animals received an intraperitoneal injection of LPS at the dose of $1 \mathrm{mg} / \mathrm{kg}$ body weight or $5 \mathrm{mg} / \mathrm{kg}$ body weight. Group III (Intervention group) mice were first injected with curcumin at the dose of $1 \mathrm{mg} / \mathrm{kg}$ or $5 \mathrm{mg} / \mathrm{kg}$ body weight for $3 \mathrm{~d}$, and then intraperitoneally injected with LPS at the dose of $1 \mathrm{mg} / \mathrm{kg}$ or $5 \mathrm{mg} / \mathrm{kg}$ body weight. Mice were sacrificed $6 \mathrm{~h}$ after LPS injection. Each group or subgroup contained 3 animals. Parts of kidney tissues were fixed in $10 \%$ formalin to prepare paraffin-embedded tissue sections for immunohistochemistry, and some parts were used for MCP-1 mRNA detection.

Immunohistochemistry For the detection of MCP-1 expression and macrophage infiltration in renal tissue, representative kidneys were harvested for each experimental group, and $3 \mu \mathrm{m}$ paraffin-embedded sections were prepared. MCP-1 expression was detected using antibodies for MCP-1 (dilution of 1 : 50, Biosource, Camarillo, CA, U.S.A.). Mouse F4/80 antigen, an approximately $125 \mathrm{kDa}$ transmembrane protein, is expressed by a majority of mature macrophages and is the best marker for this population of cells, thus rat anti-mouse F4/80 monoclonal antibody (dilution of $1: 50$, AbD Serotec, Kidlington, U.K.) was used to detect macrophage infiltration. The biotinylated secondary antibody at $1: 100$ dilution (Dako, Kyoto, Japan) was then added, followed by dimethylaminoazobenzene (DAB) staining. Finally, stained kidney sections were counterstained with hematoxylin to label the nucleus, and visualized under an inverted phase contrast microscope (Olympus Corp., Japan).

Quantification of macrophage infiltration and MCP-1 expression was achieved with image analysis software IPP6.0 (Media Cybernetics, Bethesda, U.S.A.) by determining the Optical Density (OD) of positively stained substances (light yellow, brownish yellow and brown granules). Ten views (magnification $400 \times$, no selection) in each section were analyzed by IPP6.0 and the Average Optical Density (AOD) of the 10 views was subsequently obtained. The relative amounts of macrophages or MCP-1-positive cells were expressed as the ratio of the AODs of treatment groups and control group at the same time point.

Detection of MCP-1 mRNA Expression in Renal Tissue by Real-Time PCR MCP-1 mRNA expression in mice kidneys was measured by quantitative Real-Time RT-PCR. Total mRNA of the harvested kidneys was isolated using TRIzol and reverse transcribed into cDNA as previously described. ${ }^{14)}$ SYBR Green Real-Time PCR was performed in a $15 \mu \mathrm{l}$ PCR mixture volume consisting of $7.5 \mu \mathrm{l}$ of SYBR green Real-Time PCR master mix (TOYOBO, Osaka, Japan) containing Hotmaster Taq DNA polymerase and SYBR solution, $0.3 \mu \mathrm{l}(10 \mu \mathrm{M})$ of each forward and reverse primer, $1 \mu \mathrm{l}$ of cDNA, and $5.9 \mu \mathrm{l}$ of nuclease-free water. PCR amplification reactions were performed in a Chromo4 Four-color Real-Time PCR Detection System (Bio-Rad, Calif, U.S.A.) with the following thermal cycle conditions: initial denaturation was at $95^{\circ} \mathrm{C}$ for $3 \mathrm{~min}$, followed by 40 cycles of amplification at $95^{\circ} \mathrm{C}$ for $15 \mathrm{~s}$ and annealing at $60^{\circ} \mathrm{C}$ for $45 \mathrm{~s}$. Each sample was analyzed in triplicate. Data were normalized to GAPDH and calculated as the change ( $n$-fold) in value of the treatment groups over the control groups according to the $2^{-\Delta \Delta C t}$ method. ${ }^{15)}$ Primers were designed with Premier 5.0 software with the following sequences: MCP-1, 5'-CTGGATCGGAACCAAATGA-3' (Forward), 5'-GAAAGGGAATACCATAACATCA-3' (Reverse); GAPDH, 5'-GTTGTCTCCTGCGACTTCA-3' (Forward), 5'-GGTGGTCCAGGGTTTCTTA-3' (Reverse).

Cellular Level Experiments HK-2 cells were seeded in 6-well plates at a density of $1 \times 10^{5}$ cells per well, grown to $70-80 \%$ subconfluence and maintained for $24 \mathrm{~h}$ in serumfree medium, allowing synchronization of cell growth. Then the cells were stimulated with different concentrations of LPS $(1 \mathrm{ng} / \mathrm{ml}, 100 \mathrm{ng} / \mathrm{ml}$, and $10 \mu \mathrm{g} / \mathrm{ml})$ for 4 to $24 \mathrm{~h}$. In the intervention group, the cells were pretreated with different concentrations of curcumin $(5 \mu \mathrm{M}$ and $50 \mu \mathrm{M})$ for $1 \mathrm{~h}$, and then incubated with $100 \mathrm{ng} / \mathrm{ml}$ LPS for 4 to $24 \mathrm{~h}$. Cellular RNA was extracted. The experiments were repeated at least 3 times.

Detection of MCP-1 and IL-8 mRNA Expression in HK-2 Cells The expression of MCP-1 and IL-8 mRNA in cultured HK-2 cells was also detected with SYBR Green Real-Time PCR. Procedures for RNA extraction, cDNA preparation and components of the reaction mixture were the same as those for renal tissue. Thermal cycle conditions were as follows: initial denaturation was at $94^{\circ} \mathrm{C}$ for $10 \mathrm{~min}$, followed by 40 cycles of amplification at $94^{\circ} \mathrm{C}$ for $15 \mathrm{~s}$ and annealing at $60{ }^{\circ} \mathrm{C}$ for $1 \mathrm{~min}$, with extension at $60^{\circ} \mathrm{C}$ for $1 \mathrm{~min}$. Primer sequences used were as follows: GAPDH, 5'-CAGGGCTGCTTTTAACTCTGGTAA-3' (Forward), 5'-GGGTGGAATCATATTGGAACATGT-3' (Reverse); MCP-1, 5' CAGCCAGATGCAATCAATGC-3' (Forward), 5'-GTGGTCCATGGAATCCTGAA-3' (Reverse); IL-8, 5'-GAATTGAATGGGTTTGCTAGA-3' (Forward), 5'-CACTGTGAGGTAAGATGGTGG-3' (Reverse). Each sample was analyzed in triplicate. Data analysis adopted the same method used in detecting MCP-1 mRNA expression in renal tissue.

Determination of MCP-1 and IL-8 Levels For the cytokine immunoassay, the supernatants of HK-2 cells were collected at predetermined times and the concentrations of MCP-1and IL-8 were measured using a sandwich ELISA kit according to the manufacturer's instructions. Briefly, antiMCP-1 primary antibody was coated onto ELISA plates and incubated for $120 \mathrm{~min}$ at room temperature. Samples and standards were added to the wells and incubated for $1 \mathrm{~h}$. Then the wells were washed and a biotinylated goat anti-rat MCP-1 antibody was added for $1 \mathrm{~h}$. The plates were washed again, and streptavidin conjugated to horseradish peroxidase was added for $10 \mathrm{~min}$. After washing, tetramethylbenzidine was added for color development and the reaction was terminated with $1 \mathrm{~mol} / 1 \mathrm{H}_{2} \mathrm{SO}_{4}$. Absorbance was measured at 490 $\mathrm{nm}$. Values were expressed as $\mathrm{pg} / \mathrm{ml}$.

Determination of Nuclear Factor (NF)- $\boldsymbol{B}$ B Activity The EMSA (electrophoretic mobility shift assay) method was used to detect the binding activity of transcription factor NF$\kappa \mathrm{B}$ in $\mathrm{HK}-2$ cells to the corresponding DNA sequence. $\mathrm{Nu}-$ clear proteins were extracted using the method previously described. ${ }^{14)}$ Five micrograms of nuclear extracts was incubated with $10 \times$ binding buffer, $1 \mu \mathrm{g} / \mu \mathrm{l}$ poly $(\mathrm{dI}-\mathrm{dC})$, and $1.75 \mathrm{pmol}$ biotin-labelled double-stranded NF- $\kappa \mathrm{B}$ binding consensus oligonucleotides 5'-AGTTGAGGGGACTTTCCCAGGC-3' (total volume $20 \mu \mathrm{l}$ ) using an ECL Chemiluminescent EMSA 
kit. The binding reaction was performed for $15 \mathrm{~min}$ at room temperature. The DNA-protein complexes were electrophoresed on $6.5 \%$ non-denaturing polyacrylamide gels, electrotransferred and detected according to the manufacturer's instructions. Quantitative analysis was performed using Gel Image Analysis System GIS-2318 (Shanghai Tianneng Experimental Technology Institute, Shanghai, China). Specificity of binding was also examined by using a mutant probe with the sequence of 5'-AGTTGAGGCGACTTTCCCAGGC-3'.

Statistical Analysis Results were expressed as mean S.E.M. Significant differences in the mean values were evaluated by Student's $t$-test. Intergroup variation was measured by one way analysis of variance (ANOVA) followed by Bonferroni correction. Statistical significance was considered at $p<0.05$. Statistical analysis was performed with SPSS 11.5.

\section{RESULTS}

Effect of Curcumin on Renal Pathology Induced by
LPS Macrophage infiltration and MCP-1 expression in renal tissue was evaluated after LPS injection in Kunming mice. As seen in Fig. 1A, macrophage infiltration could be observed as early as $6 \mathrm{~h}$ postinjection of LPS, showing a brown color which existed mainly in the medulla around the tubules, but less around the glomerulus in the cortex. Quantitative data showed a 16.8-fold increase of AOD compared with control $(p<0.01)$ (Fig. 1B). The increase was as high as 73.6 fold when the time increased to $72 \mathrm{~h}(p<0.01)$ (Fig. $1 B)$, with the tissue section showing an increased area and deepness of the brown color around the glomerulus and tubules in the cortex (Fig. 1A), indicating much more macrophage infiltration. The above distribution pattern of macrophage in mouse kidney after LPS injection was in agreement with the literature, ${ }^{16)}$ indicating the establishment of a renal inflammation model. Pretreatment with $5 \mathrm{mg} / \mathrm{kg}$ curcumin significantly decreased macrophage accumulation at both time points, as indicated by decreased area and deepness of the brown color in tissue sections (Fig. 1A). Quantitative data also showed that pretreatment with curcumin de-

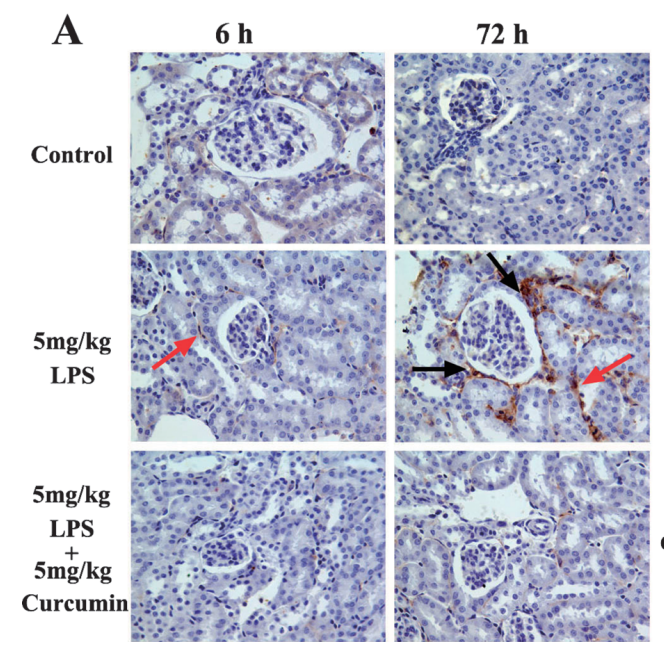

B

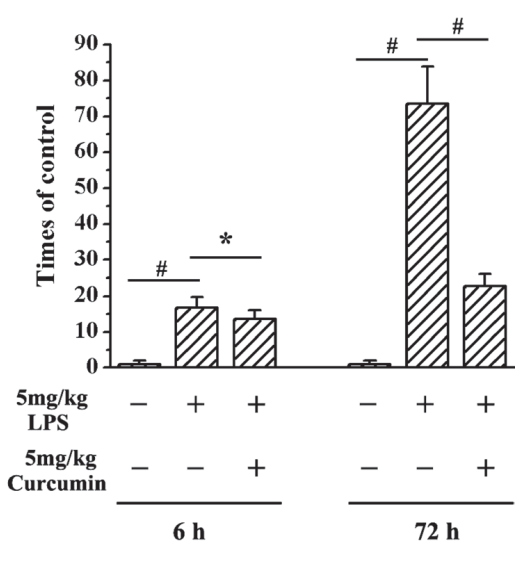

Fig. 1. (A) Representative Immunohistochemical Slides for F4/80, a Surface Marker of Macrophages from Each Group (Magnification: $\times 400$ ) and (B) Quantitative Evaluation of Macrophage Infiltration

$\# p<0.01, * p<0.05$. Red arrows indicate macrophages around the tubules, and black arrows indicate macrophages around the glomerulus.

A

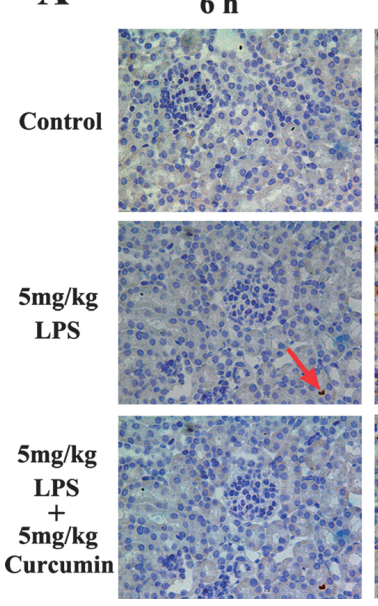

$72 \mathrm{~h}$

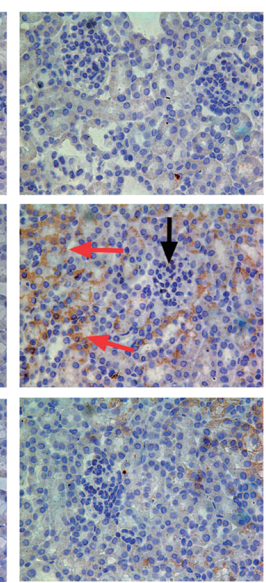

B

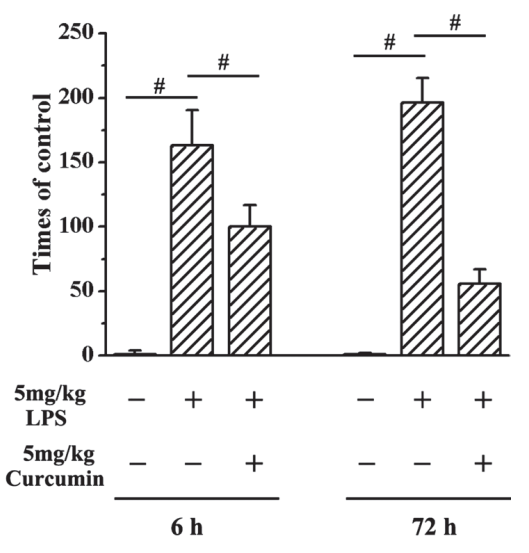

Fig. 2. (A) Representative Immunohistochemical Slides for MCP-1 from Each Group (Magnification: $\times 400$ ) and (B) Quantitative Evaluation of MCP-1 Immunohistochemistry

${ }_{\#} p<0.01$. Red arrows indicate MCP-1 around the tubules, and black arrows that around the glomerulus. 
creased macrophage infiltration to $81.0 \%(p<0.05)$ and $30.9 \%(p<0.01)$ of LPS groups at $6 \mathrm{~h}$ and $72 \mathrm{~h}$, respectively (Fig. 1B).

MCP-1 expression was another indicator of renal inflammation. Immunohistochemistry also confirmed expression of this chemokine in renal tissue after LPS injection. As seen in Fig. 2A, $6 \mathrm{~h}$ and $72 \mathrm{~h}$ after LPS injection, significant MCP-1 expression was found in renal tissue. The area with brown color mainly existed around the tubules at $6 \mathrm{~h}$ and expanded to the glomerulus at $72 \mathrm{~h}$. Quantitative data showed that MCP-1 expression increased to $163.0 \pm 27.5(p<0.01)$ and $196.5 \pm 18.9(p<0.01)$ times that of their respective controls at $6 \mathrm{~h}$ and $72 \mathrm{~h}$ respectively. Pre-injection of curcumin significantly decreased renal MCP-1 expression at both time points as demonstrated by less area and deepness of the brown color in tissue sections. Quantification results agreed with the above observation. Pretreatment with curcumin significantly decreased MCP-1 expression to $61.3 \%$ of the LPS group at $6 \mathrm{~h}(p<0.01)$, and this value further decreased to $28.5 \%$ at $72 \mathrm{~h}$, also showing a significant difference $(p<0.01)$.

Effects of Curcumin on MCP-1 mRNA Expression in Renal Tissue Induced by LPS Renal MCP-1 mRNA expression was increased to 20- and 26-fold of control when the mice were intraperitoneally injected with $1 \mathrm{mg} / \mathrm{kg}$ and

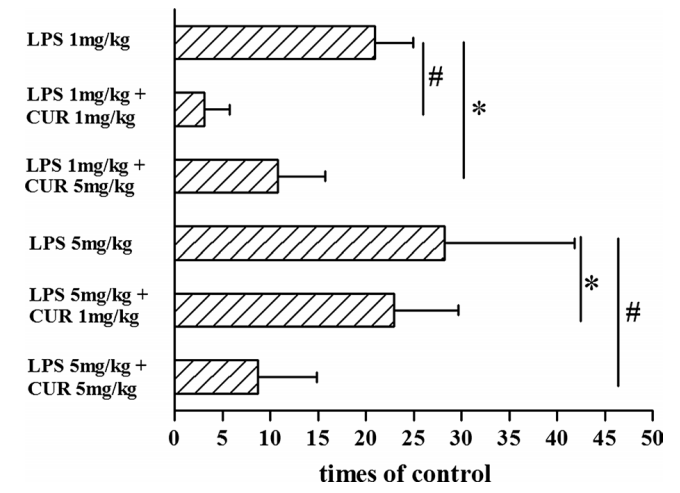

Fig. 3. Effects of Curcumin on LPS Induced Renal MCP-1 mRNA Expression

$$
* p<0.05, \# p<0.01
$$
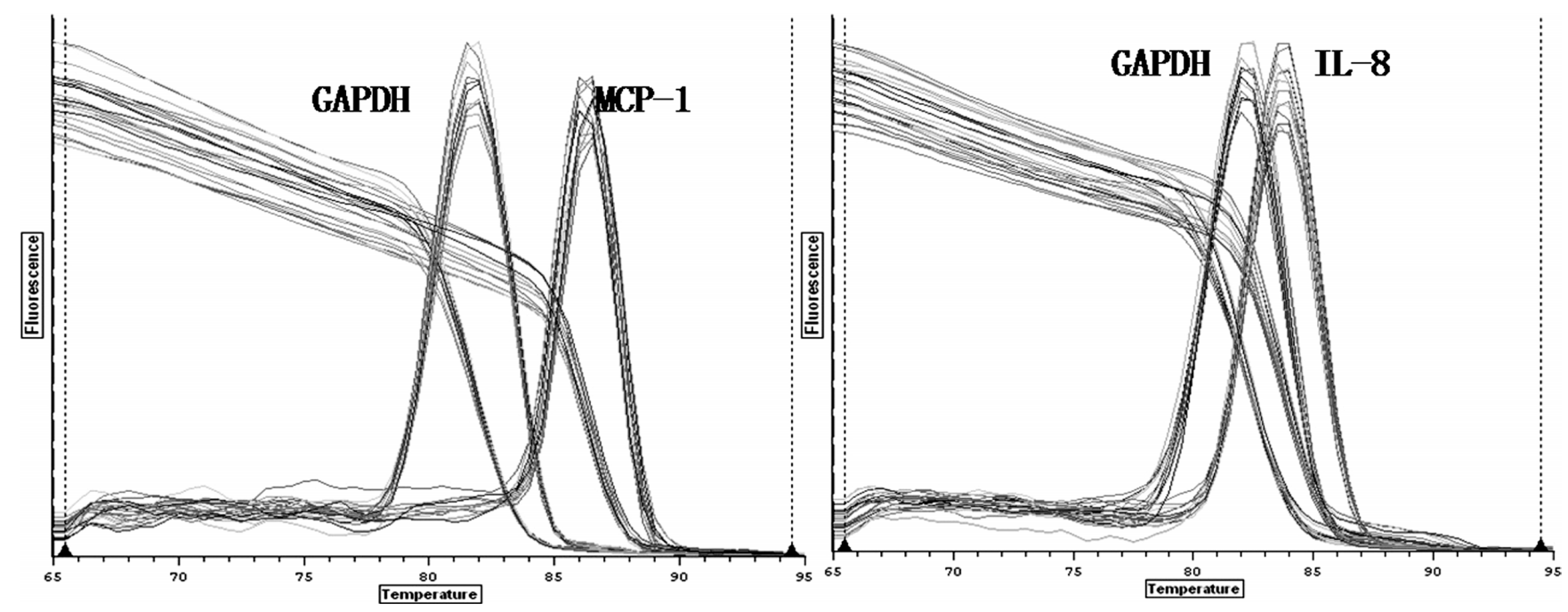

$5 \mathrm{mg} / \mathrm{kg}$ LSP, respectively, while pretreatment with curcumin significantly reduced LPS-induced renal MCP-1 mRNA expression (Fig. 3). Renal MCP-1 mRNA expression in the LPS $(1 \mathrm{mg} / \mathrm{kg})+$ curcumin $(1 \mathrm{mg} / \mathrm{kg})$ group was reduced to $14.7 \%$ that of the LPS $(1 \mathrm{mg} / \mathrm{kg})$ group $(p<0.01)$ (Fig. 3$)$.

Dissolution Curves of Real-Time PCR Product As shown in Fig. 4, the dissolution curves of the Real-Time PCR products exhibited a single-peak manner, indicating that the amplification systems were specific. Further, no non-specific product was generated.

Effects of Curcumin on LPS-Induced MCP-1 mRNA Expression in HK-2 Cells As seen in Fig. 5A, stimulation of HK-2 cells by different concentrations of LSP significantly increased cellular MCP-1 mRNA expression. It was observed that this expression increased to 1.74-, 2.15- and 14.7-fold of control when HK-2 cells were stimulated with $1 \mathrm{ng} / \mathrm{ml}, 100 \mathrm{ng} / \mathrm{ml}$ and $10 \mu \mathrm{g} / \mathrm{ml} \mathrm{LPS}$, respectively $(p<0.01)$ for $4 \mathrm{~h}$. MCP-1 mRNA expression in HK-2 cells was then gradually decreased with increasing incubation time. At $24 \mathrm{~h}$, MCP-1 mRNA expression decreased to $62.0 \%$ of control level in the $1 \mathrm{ng} / \mathrm{ml}$ LPS group $(p<0.01)$, while still maintaining a relatively high level in the $100 \mathrm{ng} / \mathrm{ml}$ LPS and $10 \mu \mathrm{g} / \mathrm{ml}$ LPS groups, 1.57- $(p<0.05)$ and 1.48 -fold $(p<0.01)$ of the control level, respectively.

Figure 5B shows the effect of curcumin pretreatment on MCP-1 mRNA expression induced by $100 \mathrm{ng} / \mathrm{ml}$ LPS in HK2 cells. It was found that curcumin $(5 \mu \mathrm{M}$ and $50 \mu \mathrm{M})$ pretreatment significantly decreased cellular MCP-1 mRNA expression at all the time points as compared with the control ( $100 \mathrm{ng} / \mathrm{ml}$ LPS group) $(p<0.01)$; a higher concentration of curcumin displayed an even stronger inhibitory effect (Fig. $5 \mathrm{~B})$. It was noteworthy that when the cells were pretreated with $50 \mu \mathrm{M}$ curcumin, the expression of MCP-1 mRNA dropped to $10.70 \%$ and $21.30 \%(p<0.01)$ of the control level after $4 \mathrm{~h}$ and $8 \mathrm{~h}$ of LPS stimulation, respectively.

Effect of Curcumin on the Secretion of MCP-1 in LPSStimulated HK-2 Cell Figure 6A shows the time course of MCP-1 concentrations in HK-2 cell supernatant after LSPstimulation. MCP-1 concentration increased with increasing LSP concentration at all time points. It was observed that MCP-1 secretion increased to 1.65-, 3.84- and 6.27-fold of

Fig. 4. Dissolution Curves of Real-Time PCR Products (MCP-1 and IL-8) 

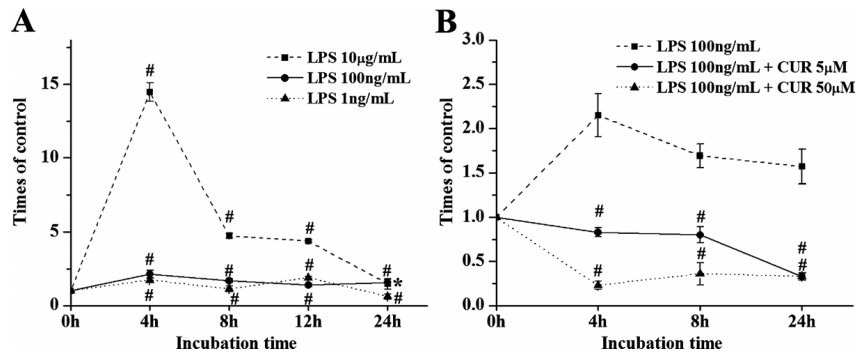

Fig. 5. (A) Effects of Different Concentrations of LPS on MCP-1 mRNA Expression in HK-2 Cells

$* p<0.05, \# p<0.01$ as compared with control.

(B) Effects of Different Concentrations of Curcumin on MCP-1 mRNA Expression Induced by $100 \mathrm{ng} / \mathrm{ml}$ LPS in HK-2 Cells

$\# p<0.01$ as compared with control (100 ng/ml LPS group at the same time point).

$\mathbf{A}$
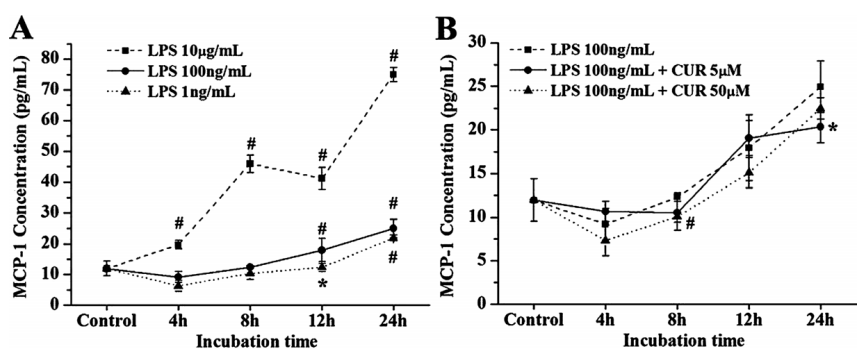

Fig. 6. (A) Effects of Different Concentrations of LPS on MCP-1 Expression in HK-2 Cells

$* p<0.05, \# p<0.01$ as compared with control.

(B) Effects of Different Concentrations of Curcumin on MCP-1 Expression Induced by $100 \mathrm{ng} / \mathrm{ml}$ LPS in HK-2 Cells

$* p<0.05, \# p<0.01$ as compared with control (100 ng/ml LPS group at the same time point).

control after $10 \mu \mathrm{g} / \mathrm{ml}$ LPS stimulation for 4,8 and $24 \mathrm{~h}$, respectively $(p<0.01)$, showing a time-dependent manner of increase. As to the $1 \mathrm{ng} / \mathrm{ml}$ and $100 \mathrm{ng} / \mathrm{ml}$ LPS groups, although a slight decrease was observed at the first time point, MCP-1 concentration gradually increased as incubation time further increased, reaching $21.87 \pm 0.96$ and $24.94 \pm 2.97$ $\mathrm{pg} / \mathrm{ml}$ at $24 \mathrm{~h}$, respectively (Fig. $6 \mathrm{~A}$ ).

As seen in Fig. 6B, pretreatment with curcumin partially inhibited LPS-induced MCP-1 secretion in HK-2 cells. At all the time points, $50 \mu \mathrm{M}$ curcumin pretreatment could inhibit LPS-induced MCP-1 secretion and significant inhibition was found at $8 \mathrm{~h}(p<0.01)$, when MCP-1 concentration was decreased by $19.5 \%$ compared with control $(100 \mathrm{ng} / \mathrm{ml}$ LPS group). In the $5 \mu \mathrm{M}$ curcumin group, significant inhibition was found at $24 \mathrm{~h}(p<0.05)$.

Effects of Curcumin on LPS-Induced IL-8 mRNA Expression in HK-2 Cells The effects of LPS on IL-8 mRNA expression in HK-2 cells were similar to those on MCP-1 mRNA expression. As seen in Fig. 7A, LPS-induced IL-8 mRNA expression in HK-2 cells displayed a clear dose- and time-dependent manner. At all investigated time points, cellular IL-8 mRNA expression increased with increasing LSP concentration. For example, IL-8 mRNA expression increased to 2.74-, 5.40- and 16.45-fold that of control level at $4 \mathrm{~h}$ when treated with $1 \mathrm{ng} / \mathrm{ml}, 100 \mathrm{ng} / \mathrm{ml}$ and $10 \mu \mathrm{g} / \mathrm{ml} \mathrm{LPS}$, respectively $(p<0.01)$. IL-8 mRNA expression underwent a dramatic increase within the first $4 \mathrm{~h}$ and then gradually decreased. Upon $24 \mathrm{~h}$ of LPS-stimulation, IL-8 mRNA expres-
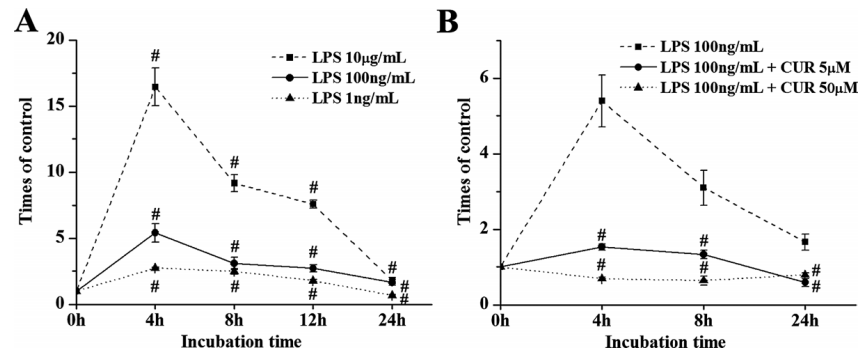

Fig. 7. (A) Effects of Different Concentrations of LPS on IL-8 mRNA Expression in HK-2 Cells

$\# p<0.01$ as compared with control.

(B) Effects of Different Concentrations of Curcumin on IL-8 mRNA Expression Induced by $100 \mathrm{ng} / \mathrm{ml}$ LPS in HK-2 Cells

$\# p<0.01$ as compared with control ( $100 \mathrm{ng} / \mathrm{ml}$ LPS group at the same time point).
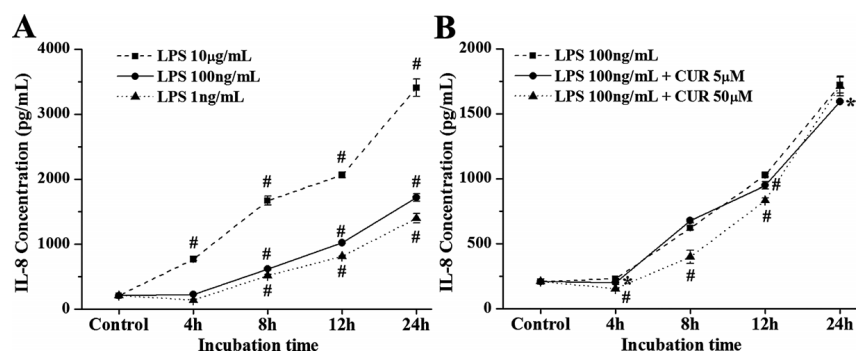

Fig. 8. (A) Effects of Different Concentrations of LPS on IL-8 Expression in HK-2 Cells

$\# p<0.01$ as compared with control.

(B) Effects of Different Concentrations of Curcumin on IL-8 Expression Induced by $100 \mathrm{ng} / \mathrm{ml}$ LPS in HK-2 Cells

$* p<0.05, \# p<0.01$ as compared with control ( $100 \mathrm{ng} / \mathrm{ml}$ LPS group at the same time point).

sion in HK-2 cells was still 1.66- and 1.79-fold of control in the $100 \mathrm{ng} / \mathrm{ml}$ and $10 \mu \mathrm{g} / \mathrm{ml}$ LPS groups $(p<0.01)$, while in the $1 \mathrm{ng} / \mathrm{ml}$ LPS group, it had decreased to $67 \%$ of control $(p<0.01)$.

The effects of curcumin on LPS-induced IL-8 mRNA expression in HK-2 cells were also similar to that on MCP-1 mRNA expression. As shown in Fig. 7B, both $5 \mu \mathrm{m}$ and $50 \mu \mathrm{M}$ curcumin pretreatment could significantly inhibit cellular IL-8 mRNA expression induced by $100 \mathrm{ng} / \mathrm{ml}$ LPS. The higher concentration, $50 \mu \mathrm{M}$ curcumin, displayed even stronger inhibitory effect, with IL-8 mRNA expression even less than basal level at all time points.

Effects of Curcumin on the Secretion of IL-8 in LPSStimulated HK-2 Cell IL-8 concentration in the supernatant of HK-2 cells showed a similar tendency as that of MCP-1. Figure 8A displays that IL-8 concentration increased with increasing incubation and increasing LPS concentration, except that a slight decrease was observed at $4 \mathrm{~h}$ incubation with $1 \mathrm{ng} / \mathrm{ml}$ LPS. The IL-8 concentration increased from the basal level of $209.7 \pm 20.4 \mathrm{pg} / \mathrm{ml}$ to $1402.1 \pm 70.3,1719.5 \pm$ 60.5 and $3405.9 \pm 135.9 \mathrm{pg} / \mathrm{ml}$ after $24 \mathrm{~h}$ incubation with $1 \mathrm{ng} / \mathrm{ml}, 100 \mathrm{ng} / \mathrm{ml}$ and $10 \mu \mathrm{g} / \mathrm{ml} \mathrm{LPS}$, respectively, all increases having significant difference $(p<0.01)$.

Figure $8 \mathrm{~B}$ demonstrats that pretreatment with curcumin inhibited the IL-8 expression induced by $100 \mathrm{ng} / \mathrm{ml}$ LPS in HK-2 cells, especially in the early stage (4 to $8 \mathrm{~h}$ ). At $4 \mathrm{~h}$ and $12 \mathrm{~h}, 5 \mu \mathrm{M}$ curcumin reduced IL-8 expression by $11.72 \%$ $(p<0.05)$ and $7.58 \%(p<0.01)$ compared with the control 


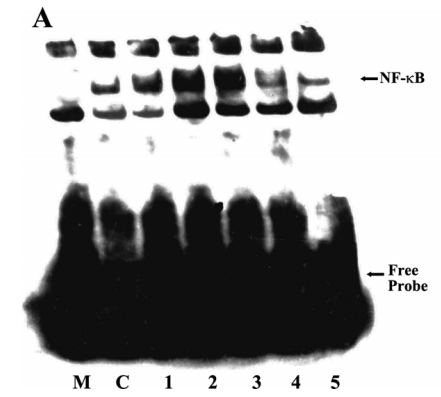

B

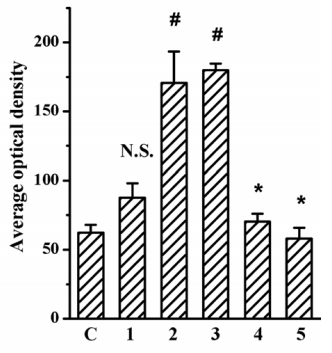

Fig. 9. (A) Effect of Curcumin on NF- $\kappa$ B DNA Binding Activity in HK-2 Cells and (B) Quantitative Analysis of NF- $\kappa$ B DNA-Binding Activity

M, Mutant probe; C, control; 1, LPS $1 \mathrm{ng} / \mathrm{ml} ; 2$, LPS $100 \mathrm{ng} / \mathrm{ml} ; 3$, LPS $10 \mu \mathrm{g} / \mathrm{ml} ; 4$, LPS $100 \mathrm{ng} / \mathrm{ml}+$ curcumin $50 \mu \mathrm{m} ; 5$, LPS $100 \mathrm{ng} / \mathrm{ml}+$ curcumin $5 \mu \mathrm{M}$. N.S., not significant, compared with control; $\# p<0.01$, compared with control; $* p<0.01$, compared with LPS $100 \mathrm{ng} / \mathrm{ml}$ group.

group, and $50 \mu \mathrm{M}$ curcumin could reduce it by $32.90 \%$ and $18.79 \%(p<0.01)$ respectively.

Effect of Curcumin on NF- $\kappa$ B Activity in LPS-Induced HK-2 Cells As seen in Fig. 9A, the control group displayed a certain degree of NF- $\kappa$ B DNA binding activity, while the mutant probe did not bind with $\mathrm{NF}-\kappa \mathrm{B}$, indicating the specificity of binding. As LPS concentration increased from $1 \mathrm{ng} / \mathrm{ml}$ to $10 \mu \mathrm{g} / \mathrm{ml}$, the bands corresponding to $\mathrm{NF}-\kappa \mathrm{B}$ showed deeper color from Lane 1 to 3 , indicating a concentration-dependent effect of LPS on NF- $\kappa \mathrm{B}$ activity in $\mathrm{HK}-2$ cells. Quantitative data showed that NF- $\kappa \mathrm{B}$ activity increased to $1.4-, 2.7$ - and 2.9-fold of the control when $1 \mathrm{ng} / \mathrm{ml}, 100$ $\mathrm{ng} / \mathrm{ml}$ and $10 \mu \mathrm{g} / \mathrm{ml}$ LPS was used, respectively (Fig. 9B). Significant difference $(p<0.01)$ was observed at the two higher concentrations. Both $5 \mu \mathrm{M}$ and $50 \mu \mathrm{M}$ curcumin significantly inhibited the $100 \mathrm{ng} / \mathrm{ml}$ LPS-induced DNA binding activity of $\mathrm{NK}-\kappa \mathrm{B}$, as evidenced by the lighter color of NF$\kappa \mathrm{B}$ bands. Quantification results showed that NF- $\kappa \mathrm{B}$ activity decreased to $41.2 \%$ and $32.0 \%$ of the $100 \mathrm{ng} / \mathrm{ml}$ LPS group when the curcumin concentrations were $5 \mu \mathrm{M}$ and $50 \mu \mathrm{M}$, respectively, both having statistical significance.

\section{DISCUSSION}

Lipopolysaccharide (LPS) is an important pro-inflammatory factor, which is able to cause endotoxemia and even shock and multiple organ dysfunction syndromes. Several models of acute renal failure and sepsis in mice have been established successfully by intraperitoneal or intravenous injection of LPS. ${ }^{13,17)}$ In the present study, curcumin, a natural product with a variety of attractive biological properties, was found to significantly and dose-dependently inhibit chemokine MCP-1 expression and macrophage infiltration in mouse kidney, thus demonstrating a protective effect against LPS-induced renal inflammation. As seen in Fig. 1 and Fig. 2 , the extent of renal MCP-1 expression and macrophage infiltration after various treatments at various times displayed similar trends. These results were indeed reasonable as the main property of MCP-1 is the attraction of monocytes/ macrophage, ${ }^{18)}$ and it been reported to recruit macrophage in kidney diseases. ${ }^{16,19)}$ We further examined the effect of curcumin on kidney MCP-1 mRNA expression induced by LPS. Significant inhibition was observed even at $1 \mathrm{mg} / \mathrm{kg}$ curcumin, while LPS concentration used was as high as $5 \mathrm{mg} / \mathrm{kg}$
(Fig. 3), suggesting the powerful effect of curcumin against renal inflammation.

With these promising results from in vivo experiments, we intended to explore the mechanism of curcumin's protective effect against LPS-induced renal inflammation using an in vitro model. The human proximal tubule cell line (HK-2 cells) was used in the present study for the following reasons. In our experiments, the results of immunohistochemistry showed that MCP-1 was present only in the renal cortex and had a punctate staining pattern in the inner portion of proximal tubules, indicating the involvement of proximal tubule cells in renal inflammation. Additionally, it had been reported that renal proximal tubular epithelial cells (TECs) are not only a major target of renal damage during renal diseases, ${ }^{20,21)}$ but also the target of LPS during sepsis and renal infections. $^{22)}$

Members of the chemokine family have mostly been classified into two broad groups based on the juxtaposition of the first two cysteine residues in their amino acid sequences. The $\mathrm{C}-\mathrm{C}$ chemokine family, typified by monocyte chemoattractant protein-1 (MCP-1), is primarily chemotactic for mononuclear leukocytes, while the $\mathrm{C}-\mathrm{X}-\mathrm{C}$ family, typified by interleukin-8 (IL-8), is primarily chemotactic for neutrophils. ${ }^{2324)}$ By Real-Time PCR, we found that LPS upregulated IL- 8 and MCP-1 mRNA expressions peaked at $4 \mathrm{~h}$ with gradual decreases as incubation time extended to $24 \mathrm{~h}$ (Figs. 5A, 7A). These results imply that the enhancing effect of LPS on IL-8 and MCP-1 are mediated through a short term activation mechanism. Keepers et al. ${ }^{16)}$ reported similar results where MCP-1 mRNA peaked even as early as at $2 \mathrm{~h}$ postinjection of LPS followed by a gradual decrease. However, the concentrations of IL- 8 and MCP-1 in cell culture media responded to the LPS stimulation in a relatively slow manner. At all tested LPS concentrations, IL-8 and MCP-1 concentrations increased with increasing incubation time at least within $24 \mathrm{~h}$. Anand et al. ${ }^{25)}$ also found that MCP-1 secretion by human dermal microvascular endothelial cells (HMVEC) and human umbilical vein endothelial cells (HUVEC) secreted upon stimulation by LPS gradually increased within $16 \mathrm{~h}$.

In vitro experiments investigating the mechanism of curcumin's protective effect against renal inflammation revealed that pretreatment of curcumin significantly and dose-dependently inhibited cellular level of MCP-1 and IL-8 mRNA, which was associated with a certain degree of decrease in MCP-1 and IL-8 concentration in cell culture media. However, the decreased level of proteins was not as significant as their corresponding mRNAs. As seen in Figs. 6B and 8B, $5 \mu \mathrm{M}$ curcumin displayed limited inhibition effect on neither the MCP-1 nor IL-8 level. With a higher concentration of curcumin $(50 \mu \mathrm{M}), \mathrm{MCP}-1$ and IL-1 levels were reduced at all time points, while significance could only be found at $12 \mathrm{~h}$ for MCP-1 and 4, 8 and $12 \mathrm{~h}$ for IL-8. Possible reasons explaining the great difference in curcumin's inhibition effect on mRNA and proteins are as follows. First of all, a series of biological process exists between mRNA and its corresponding protein, and the cellular mRNA level do not surely represent the protein level. The second reason might be due to the specific mode of action of LPS. As shown in Figs. 6A and 8A, LPS-induced MCP-1 and IL-8 secretion was a slow and ever-increasing process, at least within the experimental 
time period, indicating the enhancement or at least maintenance of the effect of LPS; thus curcumin might only be effective on the early stage but become less powerful as incubation time increases. As a matter of fact, we did find a significant inhibition effect of $50 \mu \mathrm{M}$ curcumin prior to $12 \mathrm{~h}$. Finally, despite its cytoprotective effect, ${ }^{26)}$ curcumin was recently found to be cytotoxic against $\mathrm{HK}-2$ cells at $\left.50 \mu \mathrm{M}^{27}\right)$ Although no clear evidence supported the possible positive effect of curcumin on the synthesis, sorting and secretion of these two proteins, the relatively higher concentration of curcumin used herein should be considered when explaining these results. On the other hand, the fact that $5 \mu \mathrm{M}$ curcumin showed a limited inhibition effect against MCP-1 and IL-8 secretion might be due to the relatively lower concentration.

Compared with the significant inhibition of macrophage infiltration and MCP-1 expression in mouse kidney by pretreatment of curcumin, its in vitro inhibition effect against MCP-1 and IL- 8 secretion was relatively limited. A possible explanation is that the MCP-1 expression detected by immunohistochemistry represented the total MCP-1 both in and out of the cells, while ELISA only determined the MCP-1 in the culture media, that is to say, out of the cells.

$\mathrm{NF}-\kappa \mathrm{B}$ is a multi-unit transcription factor that plays a central role in the induction of pro-inflammatory cytokine gene expression. ${ }^{28)}$ In resting cells, NF- $\kappa \mathrm{B}$ resides in the cytosol through interaction with $\mathrm{I} \kappa \mathrm{B}$ (inhibitor of $\kappa \mathrm{B}$ ) inhibitory proteins. I $\kappa \mathrm{B}$ becomes phosphorylated, ubiquitinated and then degraded when exposured to stimuli. Thus, the activated $\mathrm{NF}-\kappa \mathrm{B}$ is translocated to the nucleus, and induces the transcription of the target gene. ${ }^{29)}$ It has been reported to be activated in response to a broad range of stimuli and conditions, including LPS. ${ }^{30)}$ In this study, HK-2 cells were used to examine the effect of curcumin on LPS-induced DNA binding activity of NF- $\kappa \mathrm{B}$ in TECs. Although no quantification was carried out in our experiments, a significant and dosedependent inhibition effect was indeed observed. Previously, $\mathrm{NF}-\kappa \mathrm{B}$ was reported to activate the MCP-1 gene ${ }^{31,32)}$ and IL8 gene expression. ${ }^{33,34)}$ It is possible that curcumin inhibits $\mathrm{NF}-\kappa \mathrm{B}$ activity, subsequently inhibiting the transcription of MCP-1 and IL-8 mRNA and finally inhibiting the expression of MCP-1 and IL-8.

In summary, we herein demonstrated that curcumin was able to attenuate LPS-induced renal inflammation by inhibiting MCP-1 expression and macrophage infiltration in mouse kidney. Mechanistic studies revealed that curcumin significantly and dose-dependently inhibited mRNA expression of MCP-1 and IL-8 in TECs, and that also inhibited MCP-1 and IL-8 expression at higher concentrations at the early stage of LPS stimulation. Curcumin was also found to inhibit LPSupregulated NF- $\kappa \mathrm{B}$ activity which might be attributable to its inhibition effect on MCP-1 and IL-8 mRNA expression. These findings provide a theoretical basis for further utilization of curcumin in renal inflammation.

\section{REFERENCES}

1) Ammon H. P., Wahl M. A., Planta Med., 57, 1-7 (1991)

2) Sikora E., Scapagnini G., Barbagallo M., Immun. Ageing, 7, 1 (2010).

3) Epstein J., Sanderson I. R., Macdonald T. T., Br. J. Nutr., 103, 1045-1057 (2010).

4) Sumanont Y., Murakami Y., Tohda M., Vajragupta O., Matsumoto K., Watanabe H., Biol. Pharm. Bull., 27, 170-173 (2004).

5) Mahakunakorn P., Tohda M., Murakami Y., Matsumoto K., Watanabe H., Vajaragupta O., Biol. Pharm. Bull., 26, 725-728 (2003).

6) Shoskes D. A., Transplantation, 66, 147-152 (1998).

7) Kuwabara N., Tamada S., Iwai T., Teramoto K., Kaneda N., Yukimura T., Nakatani T., Miura K., Urology, 67, 440-446 (2006).

8) Kuhad A., Pilkhwal S., Sharma S., Tirkey N., Chopra K., J. Agric. Food Chem., 55, 10150-10155 (2007).

9) Jones E. A., Shoskes D. A., J. Urol., 163, 999-1004 (2000).

10) Ghosh S. S., Massey H. D., Krieg R., Fazelbhoy Z. A., Ghosh S., Sica D. A., Fakhry I., Gehr T. W., Am. J. Physiol. Renal. Physiol., 296, F1146-F1157 (2009).

11) Bascands J. L., Bachvarova M., Neau E., Schanstra J. P., Bachvarov D., Bioochem. Biophys. Res. Commun., 386, 407-412 (2009).

12) Zhang W. J., Wei H., Hagen T., Frei B., Proc. Natl. Acad. Sci. U.S.A., 104, 4077-4482 (2007).

13) Lee S., Kim S., Kang K. P., Moon S. O., Sung M. J., Kim D. H., Kim H. J., Park S. K., Nephrol. Dial. Transplant., 20, 1057-1065 (2005).

14) Bruemmer D., Collins A. R., Noh G., Wang W., Territo M., Arias-Magallona S., Fishbein M. C., Blaschke F., Kintscher U., Graf K., Law R. E., Hsueh W. A., J. Clin. Invest., 112, 1318-13131 (2003).

15) Livak K. J., Schmittgen T. D., Methods, 25, $402-408$ (2001).

16) Keepers T. R., Gross L. K., Obrig T. G., Infect. Immun., 75, 1229 1236 (2007).

17) Granholm N. A., Cavallo T., Lupus, 3, 507-514 (1994).

18) Viedt C., Orth S. R., Nephrol. Dial. Transplant., 17, 2043-2047 (2002).

19) Lynn E. G., Siow Y. L., Frohlich J., Cheung G. T., O. K., Kidney Int., 60, 520-532 (2001).

20) Waeckerle-Men Y., Starke A., Wahl P. R., Wüthrich R. P., Kidney Blood Press. Res., 30, 421-429 (2007).

21) Dieguez-Acuña F. J., Polk W. W., Ellis M. E., Simmonds P. L., Kushleika J. V., Woods J. S., Toxicol. Sci., 82, 114-123 (2004).

22) Bussolati B., David S., Cambi V., Tobias P.S., Camussi G., Int. J. Mol. Med., 10, 441- 449 (2002).

23) DeVries M. E., Ran L., Kelvin D. J., Semin. Immunol., 11, 95-104 (1999).

24) Scapini P., Lapinet-Vera J. A., Gasperini S., Calzetti F., Bazzoni F., Cassatella M. A., Immunol. Rev., 177, 195-203 (2000).

25) Anand A. R., Bradley R., Ganju R. K., Mol. Immunol., 46, 962-968 (2009).

26) Sood A., Mathew R., Trachtman H., Biochem. Biophys. Res. Commun., 283, 36-41 (2001).

27) Hu Y., Liang H., Du Y., Zhu Y., Wang X., Am. J. Nephrol., 31, 332341 (2010).

28) Baeuerle P. A., Henkel T., Annu. Rev. Immunol., 12, 141-179 (1994).

29) Bowie A., O’Neill L. A., Biochem. Pharmacol., 59, 13-23 (2000).

30) Stancovski I., Baltimore D., Cell, 91, 299-302 (1997).

31) Gawaz M., Neumann F. J., Dickfeld. T., Koch W., Laugwitz K. L., Adelsberger H., Langenbrink K., Page S., Neumeier D., Schömig A., Brand K., Circulation, 98, 1164-1171 (1998).

32) Rovin B. H., Dickerson J. A., Tan L. C., Fassler J., Cytokine, 9, 178 186 (1997).

33) Tabary O., Muelaet C., Escotte S., Antonicelli F., Hubert D., Dusser D., Jacquot J., Am. J. Pathol., 162, 293-302 (2003).

34) DiMango E., Ratner A. J., Bryan R., Tabibi S., Prince A., J. Clin. Invest., 101, 2598-2606 (1998). 